\title{
RELIABILITY MODEL OF THE RTC SYSTEM WITH TRACKSIDE EQUIPMENT EQUIPPED WITH A PELTIER CELL
}

\author{
Rafał Kowalik $^{1, *(\mathbb{D})}$, Emil Sadowski ${ }^{2}$ \\ ${ }^{1}$ Aviation Military University, Faculty of Aviation, Department of Avionics and Control Systems, Poland, email: r.kowalik@law.mil.pl, \\ https://orcid.org/0000-0001-6431-9561 \\ ${ }^{2}$ Service and Trade Company HESTA (PUH HESTA) in Radom, Poland \\ * Corresponding author
}

Reviewed positively: 17.06 .2020

Information about quoting an article:

Kowalik R., Sadowski E. (2020). Reliability model of the RTC System with trackside equipment equipped with a Peltier cell. Journal of civil engineering and transport. 2(2), 99-108, ISSN 2658-1698, e-ISSN 2658-2120, DOI: 10.24136/tren.2020.008

\begin{abstract}
The article presents a mathematical model assessing the reliability of rail traffic control systems with a mounted Peltier cell. The semiconductor element will be used for operating electronic components that are in the trackside equipment. In the prepared model, Markow processes were used to describe the states occurring between individual components of the RTC System. Simulation tests were mainly based on determining the average time of component failure. The presented results were carried out for 1,000, 2,000 and 3,000 rail vehicle crossings over the railway tracks equipped with RTC Systems. At the very end of the article the conclusions resulting from computer simulations were presented.
\end{abstract}

Key words - RTC System, MTTF, reliability, Peltier cell

JEL Classification - R41

\section{INTRODUCTION}

The model determining the reliability of the developed Railway Traffic Control RTC System with a Peltier cell is based on data on the maintenance of trackside and signaling equipment, it also takes into account all relevant indirect factors, such as atmospheric factors affecting the operation of the RTC System (e.g. environment, human error, etc.), which are quantitatively related to the probability of a fault occurring in the RTC System [2, 4-5, 9-10]. System reliability analysis can be automatically performed on the software platform using the existing algorithms responsible for controlling RTC Systems $[1,3,7,11]$. Data collected at this stage are recorded as input for the developed reliability model. Therefore, it was assumed that the research will be based on empirical data, which means that if a failure occurs, it generally does not affect the proper functioning of the other components included in the RTC System, this does not apply to the tracking elements of the system, so they will not be taken into account in mathematical analysis [6, 16, 21-22].

In order to develop a reliability model, which takes into account only the parameters recorded in the technical document for the railways, and contains information about the maintenance carried out [19-20]. Based on the results of the exploratory analysis and carrying out corrective actions in the scope of the parameters of parameters characterizing the correct operation of electronic trackside elements regarding the correct maintenance of track movement, the model includes the following parameters [17-18, 24, 26]:

- Symptom: a symptom that identifies a failure and launches the RTC component supervision system, usually observed by the technical worker responsible for track maintenance, defined defects and system activation,

- System / subsystem assets: assets for which corrective actions are carried out,

- Real failure: a failure related to the elements of the system supervising the operation of RTC components,

- Cause of failure: reason of failure,

- Corrective action: action taken to shut down the RTC system,

- Failure date: date when events were generated in the RTC system. 


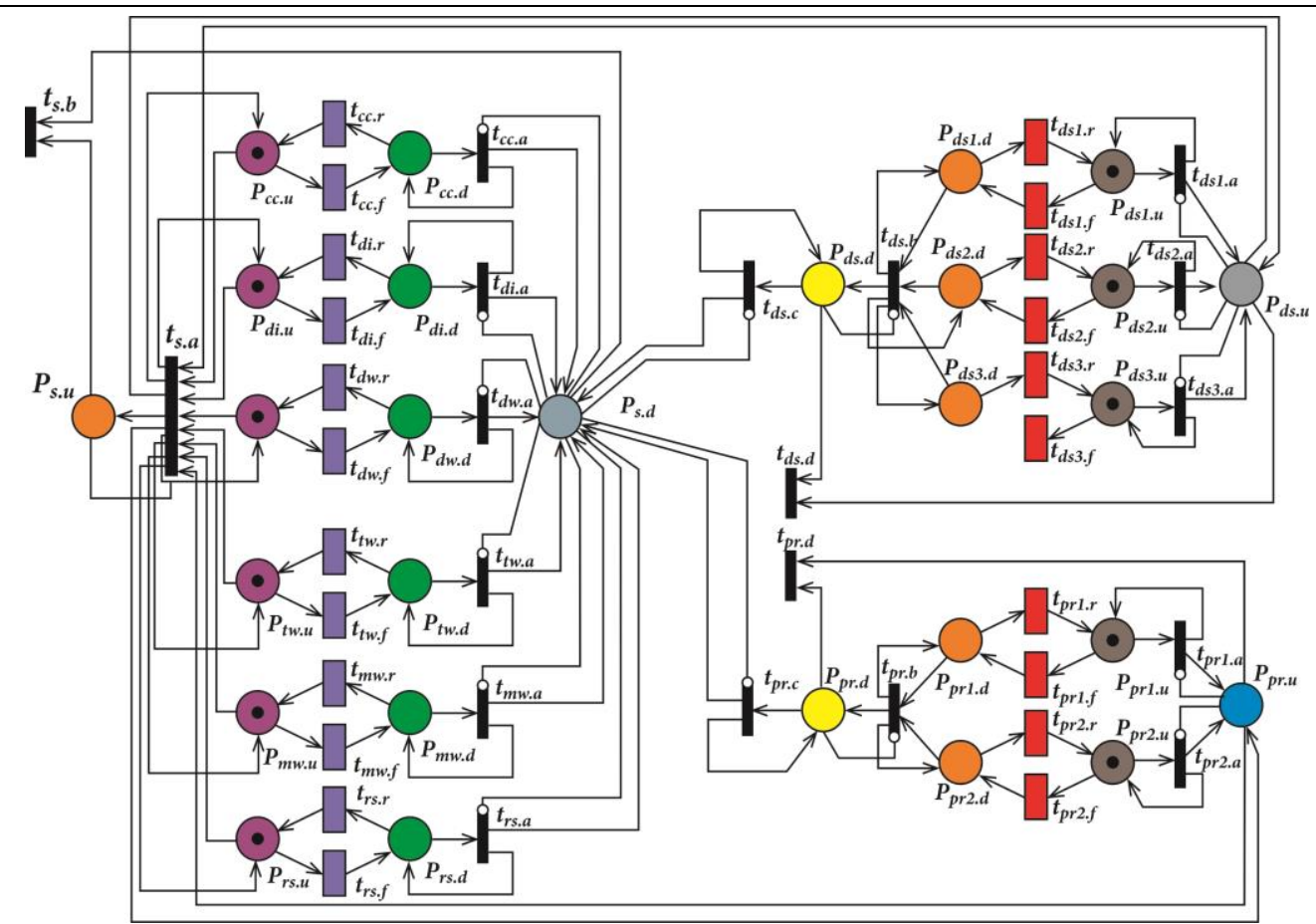

Fig. 1. Diagram of state connections in the RTC reliability system with trackside equipment

Figure 1 presents the proposed decision support model based on the maintenance of data from persons involved in tracks quality supervision. Various results can be obtained, but the most important of them is the measurement of the failure rate, availability and ease of maintaining the RTC System operation efficiency does not apply to data collected from subsystems not directly entering the reliability system. This provides a multidimensional tool for measuring the repair maintenance process of components included in the RTC System. The combination of the same corrective actions on different assets allows comparison of procedures and identification of the best methods of repair practice of components of the RTC System [12-14].

The dependence between the causes of failures modeled in the software and the actual failures allows the identification of the factors that most affect the reliability of the RTC System equipped with a Peltier cell, which leads to the conclusion that further actions can be oriented to reduce the typical causes of RTC equipment failure. Relations between parameters, e.g. between actual failures and corrective actions, provide insight into the performance of maintenance carried out with and without a Peltier cell, this may indicate areas where the use of a Peltier cell would provide the greatest benefits in terms of rail traffics maintenance. The relationship between the actual failures and the causes of the failures can be determined by possible actual failures that can help to limit the corrective actions regarding the maintenance of RTC components [25, 27-28].

The proposed model identifies possible areas for improvement in the reliability of RTC Systems. It will allow enterprises to review their planning processes for the launch of RTC Systems, prepare and maintain them, and will also result in remarks to contractors of individual elements of RTC. It discusses how various changes in the policy for maintaining the functionality of the RTC System (e.g. preventive inspections, repair procedures for maintaining electronic components of the RTC, identification of defects, etc.) affect the reliability of the systems (e.g. increasing availability and reliability, reducing Travel time reliability - TTR etc.) [15].

Ultimately, the model can contribute to the study of various maintenance policies for RTC System components and life cycle cost analysis (LCC). There are some ambiguities in the LCC due to 
the statistical reliability characteristics and the ability to maintain parameters such as Mean Time To Failure - MTTF and Mean Time To Repair - MTTR [23]. LCC analyses can be used to focus on strategies to maintain the correct functionality of the RTC System to minimize maintenance costs over the system's life cycle while meeting reliability requirements.

\section{CONFIgURATION MANAGEMENT TO PROVIDE TECHNICAL SUPPORT}

This section of the article proposes a model of the system assessing the correct level of the RTC System, in order to improve the service of electromechanical devices included in the trackside system by improving information logistics. In this process, it establishes three key elements base points:

- Specifies the required base points and the components that make up them,

- Tracks and distributes changes and modifications of both RTC System configurations along with the processes taking place there,

- Ensures the integrity of individual subsystems that make up the main RTC System of the basic configuration.

Baselines describe the status of a specific RTC System at a given time. They can be used as a reference for tracking changes (e.g. replacement of elements due to failures) in the RTC System. They can also be specified for a specific item and show the changes made to a specific system subassembly over a period of time.

The necessary basic lines for managing the configuration of Polish railways equipped with RTC and signaling systems are:

- Main baseline - any design solution can be described as part (e.g. different project baselines depending on whether the ATC, ERTMS or SW system is operating). It integrates all information about the Automatic Train Control - ATC, European Railway Traffic Management System - ERTMS system into one information transmitted to the RTC System.

- Installation baseline - It describes how the project baseline is implemented in various environments, for e.g. the number of systems and subsystems and the mounting location where specific RTC Systems are located. The data obtained at this the stage depend on external parameters (e.g. speed limits, number of switches and crossings and the status of components related to a particular system (if it is in operation, it is being restored or in the warehouse)).

- Basic documentation: It collects all documents related to the system, subsystems and secondary components included in the RTC System.

Each element of the RTC System configuration has related information in different baselines. To this end, a procedure should be made to show all information related to the object in which the Peltier system has been mounted (e.g. location, software, etc.). Information on carried out maintenance can also be included here.

\section{PARAMETERS OF THE RELIABILITY SYSTEM}

The basic parameters assessing the reliability of a system composed of electromechanical objects with real renewal time are:

- damage intensity $\lambda$,

- renewal intensity $\mu$

Identify applicable funding agency here. If none, delete this text box.

Damage intensity (temporary) $\lambda(t)$ is the limit of the ratio of the conditional probability that the moment of damage to the object will be in a given time interval $(t, t+\Delta t)$ to the length of this time $\Delta t$ for $\Delta t$ going to zero [8].

Repair intensity (temporary) $p(t)$ is the limit of the ratio of the probability of conditional termination of service (repairs, renewals) of the object in the time interval $(t, t+\Delta t)$ to the length of this time $\Delta \mathrm{t}$ for $\Delta \mathrm{t}$ going to zero [8].

In the case of constant value of damage intensity $X$ and intensity of repair $p$, reliability indicators are also used:

average time to MTTF damage

$$
\mathrm{MTTF}=\frac{1}{\lambda}
$$

average time of MTTR renewal

$$
\mathrm{MTTR}=\frac{1}{\mu}
$$

average time between Mean Time Between Failures - MTBF failures

$$
\mathrm{MTBF}=\mathrm{MTTF}+\mathrm{MTTR}
$$

For a reliable assessment of the object's operation, it is important that the object is in a state of exploitability. This probability is called readiness $A$. For constant values of $\mu$ and $\lambda$, readiness $A$ is equal to: 3 


$$
A=\frac{\mu}{\lambda+\mu}
$$

The notion of not ready $U$ is also used, which is equal to:

$$
\mathrm{U}=1-\mathrm{A}
$$

For the elements of the telecommunications network, a constant value of damage intensity $\lambda$ and a constant value of repair intensity $\mu$ were adopted.

When considering the analysis of complex systems containing elements with known reliability parameters, a number of structures are considered, the most important of which are the following $[2,7-8,15]$ :

- row structure,

- parallel structure,

- mixed structures,

- structures with threshold elements.

A system with a row reliability structure consisting of $n$ elements (blocks) is in a state of fitness only if all its elements are in a state of fitness.

The suitability of a row system requires the fitness of all components, and failure of one component is enough to damage it. In the case of constant values of $\mu$ and $\lambda$ of individual components, the system damage intensity $\lambda$ is equal to:

$$
\lambda=\sum_{i=1}^{n} \lambda_{i}
$$

and $A_{u}$ readiness is equal to:

$$
A_{u}=\prod_{i=1}^{n} A_{i}
$$

In a parallel system with $\mathrm{n}$ elements, only one element is capable of being system-fit. The parallel system can be treated as a system with n-1 spare elements.

If the system contains $\mathrm{n}$ elements with exponential reliability functions with equal fault intensities, i.e. $\lambda 1=\lambda 2=\ldots=\lambda n=\lambda$, the expected MTTF fitness time is:

$$
\mathrm{MTTF}_{\mathrm{u}}=\left(1+\frac{1}{2}+\frac{1}{3}+\ldots+\frac{1}{\mathrm{n}}\right) \cdot \mathrm{MTTF}
$$

$A_{u}$ system readiness is equal to:

$$
A_{u}=1-\prod_{i=1}^{n}\left(1-A_{i}\right)
$$

The threshold structure $\mathrm{k} z \mathrm{n}$ can be considered to be a system containing $n$ elements that will be fit to use if at least $k$ its elements are fit $(1<k<n)$.

If the readiness of the elements included in the threshold structure are the same, i.e. $A_{1}=A_{2}=A_{3}=$ $\ldots=A n=A$, the readiness of the system can be calculated using the relationships resulting from the binomial distribution. For the threshold system $\mathrm{k} \mathrm{z} \mathrm{n}$, the readiness $A_{k z n}$ is determined by the relationship:

$$
A_{k z n}=\sum_{r=0}^{n-k}\left(\begin{array}{l}
n \\
r
\end{array}\right) A^{n-r}\left(1-A_{i}\right)^{r}
$$

If the reliability parameters of the elements included in the threshold structures are not the same, the readiness of the system is determined by analyzing equivalent series-parallel structures [8, 16]:

a) information inflow,
b) impulse delivery.

\section{SECURITY AND AVAILABILITY ASSESSMENT}

The model developed here is based on a combination of different types of information obtained from maintenance data, operational data and railway infrastructure. It examined the impact of trackside equipment failure on the overall performance of RTC Systems in terms of safety and reliability.

The model is based on Markov processes with discrete states and continuous time. It is used to calculate the probability of various operational states (safe operation, non-operational or operational operation of the system in emergency modes) of the track section, identification of RTC Systems that have the greatest impact on safe railway operation. Depending on which system there is a failure and the operational status of the railway, the model takes into account different operational states. Various scenarios are considered to validate the model, including mean values, worst and best scenarios, simulation of the effects of improved reliability and susceptibility on consequences etc. Finally, as part of detecting the current state of the RTC System, the results are combined to show the impact of RTC devices on work of other systems included in the infrastructure.

Depending on the affected RTC subsystem, three operational states are generated for the railway infrastructure under consideration. 11 states are generated that determine the various operational states and track-side equipment status 
(indicating which system has failed). These states are described on Figure 1. The last two columns of the table graphically show the state of safety and availability and how these states change depending on the state of the railway: a yellow (and happy) face when a small, green yellow (and neutral) face during work in emergency mode and a red (and sad) face when the signaling system is not secure or when there is a failure on the infrastructure (Tab. 1).

\section{Reliability MOdel}

The reliability model in this study mainly concerns the model for trackside equipment and RTC control systems, and takes into account important devices in the railway signaling control center. The developed model does not include systems such as the IT network, interface devices in the RTC control center. As the number of elements of the system increases, the number of states in which it may be located increases rapidly. This makes it difficult to estimate the reliability of more complex systems, due to the need to build a graph of transitions between all the states under consideration, as well as the need to identify the possibilities of the transitions themselves. With these four possible states of each object, manual construction of the graph of transitions, already for a structure with three elements, becomes very time consuming. For a system consisting of two objects, a graph has been built, introducing simplifications related to the connection of states of identical systems due to its suitability. The reliability model for trackside mechanical-electronic devices is shown in Figure 2.

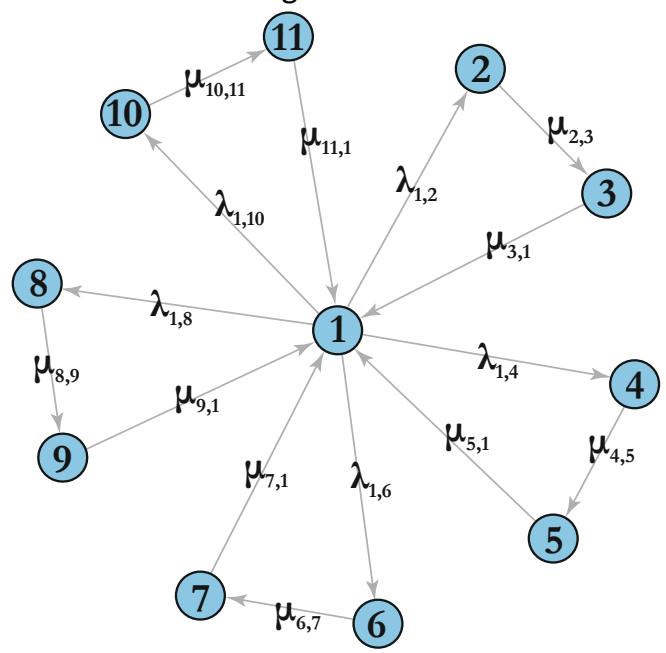

Fig. 2. Reliability model using Markov processes
Table 1. System reliability states for Figure 1

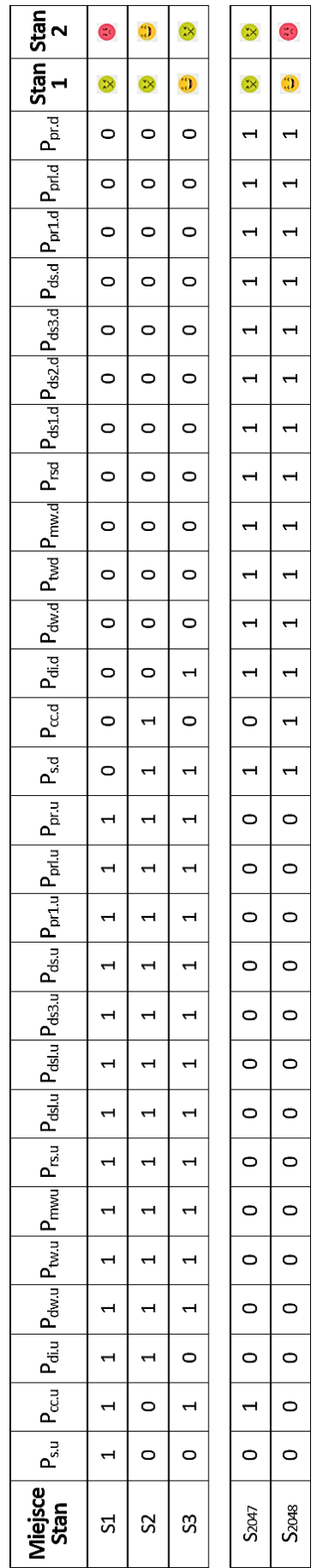


In the reliability model, as shown in Figure 2 points for which reliability analysis (RTC devices) is performed, determined by the function $\mathrm{Px}, \mathrm{u}(\mathrm{x}=\mathrm{cc}$, $\mathrm{di}, \mathrm{dw}, \mathrm{tw}, \mathrm{mw}, \mathrm{rs}, \mathrm{ds} 1, \mathrm{ds} 2, \mathrm{ds} 3, \mathrm{pr} 1, \mathrm{pr} 2$ ), $\mathrm{Px}, \mathrm{d}$ transitions $t x, f, t x, r$ between sites consisting of subnets for failure description and maintenance of RTC control devices (when $x=c c$ ), the display provides information about the failure in the system (when $x=d i$ ), the workstation analyzes the data (when $x=d w$ ), the workstation for training / simulation purposes (when $x=t w$ ), the workstation for technical support (when $x=m w$ ), the report server about failures (when $x=r s$ ), dispatcher workstation 1 and 2 (when $x=d s 1$ and ds2) dispatcher's main workstation (when $x=d s 3$ ), RTC device with a Peltier element (when $x=$ pr1) and without a Peltier link (when $x=p r 2$ ). The Px, $u$ and $P x, d$ sites express the normal state and the error of the state of the element $x$. Operations $t x, f i t x, r$ indicate the failure and maintenance procedure, the designation of the damaged element can be determined by $\lambda x$ and $\mu x$ ( $\lambda x$ and $\mu x$ is the failure rate and the component maintenance indicator $x$ ). To this end, the Py, $u(y=d s, p r, s$, same thing below) and $P y, d$ are used to describe the normal and fault status of track-side equipment, RTC equipment and signaling systems, respectively.

Reliability network, which is used to determine reliability for 3000 attempts to switch on RTC state devices, which can be marked as S1 S3000.

To calculate the system availability, the $\Omega T$ can be divided into normal and failure states (they are marked as $\Omega U$ and $\Omega D$, respectively). Because if and only if $\mathrm{i} \#($ Ps.u $)=1$, the railway signaling system is working properly, otherwise the system is in a state of failure. Therefore, the number of normal states is 21 , and the normal state is $\Omega U=\{\mathrm{S} 1, \mathrm{~S} 8$, S9, S10, S11, S12, S58, S59, S60, S61, S62, S63, S64, S65, S66, S224, S225, S226, S227, S229, S230\}. The other states are a fault whose number is 2027 and the fault status is marked as $\Omega D$ due to the design limitation of RTC elements. States cannot be listed here.

To obtain the availability indicator through reliability analysis, the railway signaling system control center model, first, the failure rate and maintenance indicator of the $x$ component, which is a component of the RTC System, workplace diagram, training / simulation station, RTC maintenance equipment, report server, dispatcher workstation 1, dispatching station 2, main dispatcher control system RTC, devices with and without Peltier cell, can be set according to real parameters, i.e. the factor $\lambda x$ and $\mu x$ of component $x$. As an example, in this article it is assumed that al the above indicator equipment was $\lambda=2.0 \times 10^{-5} \mathrm{~h}$, $\mu \mathrm{x}=0.5 / \mathrm{h}$. Then, the probability of the steady state $\pi$ vector of the entire system can be obtained by using equation 3 and equation 4 . Then, the reward for the assessment in the normal state set $\Omega U$ is equal to 1 , and the reward for marking in the set failure state $\Omega D$ is 0 , the availability of the steady state index the system can be obtained using equation 8 , and the ASS is 0.9994 . Thus, whether the system meets the steady state condition, the accessibility requirements can be analyzed.

\section{RESULTS FROM SIMULATION TESTS}

When considering the effectiveness of reliability structures of systems such as transport, one should point to kzn type threshold structures. If the system or system has a kzn type structure and consists of homogeneous and renewable objects, then $n-k$ is a parameter directly affecting the reliability and efficiency of the system. Estimating reliability in this case can be done by analytical methods such as Markov processes. The analysis analyzes the intensity of damage to objects, stand up $\lambda$, reserve stand up $\lambda r$, and renewal intensity as $\mu$. For cases when the reserve is a hot reserve (directly used in the implementation of the task), $\lambda r=\lambda$. The number of fitness states that kzn system may be in (when $\lambda r=\lambda$ ) is always 1 greater than the difference between $\mathrm{n}$ and $\mathrm{k}$, i.e. 1 greater than the number of reserve objects. The presented model may be useful for real systems in reliability assessment, enabling the recording and solution of Kolmogorov's differential equations. The condition is a small number of reserve facilities. Estimating the reliability of systems consisting of renewable technical facilities constituting fixed assets used for the implementation of production can be carried out by various methods. In particular, they can be methods in which analytical dependencies are used or methods based on computer simulation. In the theory of reliability analysis, methods using Markov processes can be used (Fig. 2) to describe changes in the technical conditions of the system during its operation. Current computer programs used for analyzing and assessing structural reliability enable automatic rapid identification of structures based on a graphic description. One of the examples to be used in works related to the analysis and assessment of the reliability of complex technical systems, including production and transport, may be the applications of the Mathematica software package intended for analyzing the reliability of renewable systems with 
different reliability structures. In the analyzed case, it was assumed that the number of rail vehicles passing through the tracks is the same for RTC elements with and without a Peltier cell, in specific time intervals it is the same and takes place on the same tracks, which results from the adopted reliability model. It was assumed that only 3,000 rail vehicle journeys were included in the analysis sample.

Modeling and simulation of the reliability system assessing RTC elements equipped with a Peltier cell and its lack using Mathematica simulation software. The main purpose of modeling and simulating the operation of the RTC System was to compare the performance of the current system with the performance of the RTC Systems installed in the Peltier cell. In the developed simulation model taking into account the average time between failures - MTBF of the RTC System

Due to the lack of accurate information, the MTBF of the manipulator is a statistical exponential distribution showing the average intensity of failures once in 1000, 2000, 4000,6000, 8000 and $10,000 \mathrm{~min}$ and a random selection of the manipulator repair time (MTTR - Mean Time to Repair) from between 50 and 100 minutes.
Simulation studies show that the inclusion in the simulation model of the analyzed system interference disturbance (manipulator failure), determined using the MTBF indicator, increases the detail of the model, which leads to increased difficulties during modeling and an increase in the number of data that must be processed during the simulation experiment. As the results of simulation studies show, the performance of the analyzed RTC System with a Peltier cell decreases as the number of failures increases in the analyzed period of operation.

\section{SUMMARY}

Due to the structure and function of the control center of the RTC Systems control system, this document establishes the reliability model by SRN, and then provides a practical method of credibility analysis for control purposes for the center of the RTC System. Graphic modeling, ability of the RTC System to analyze the reliability of the system makes the model intuitively described, at the same time described as the automatic generation of reports on the system's state of operation, which makes the method worth strong mathematical skills.
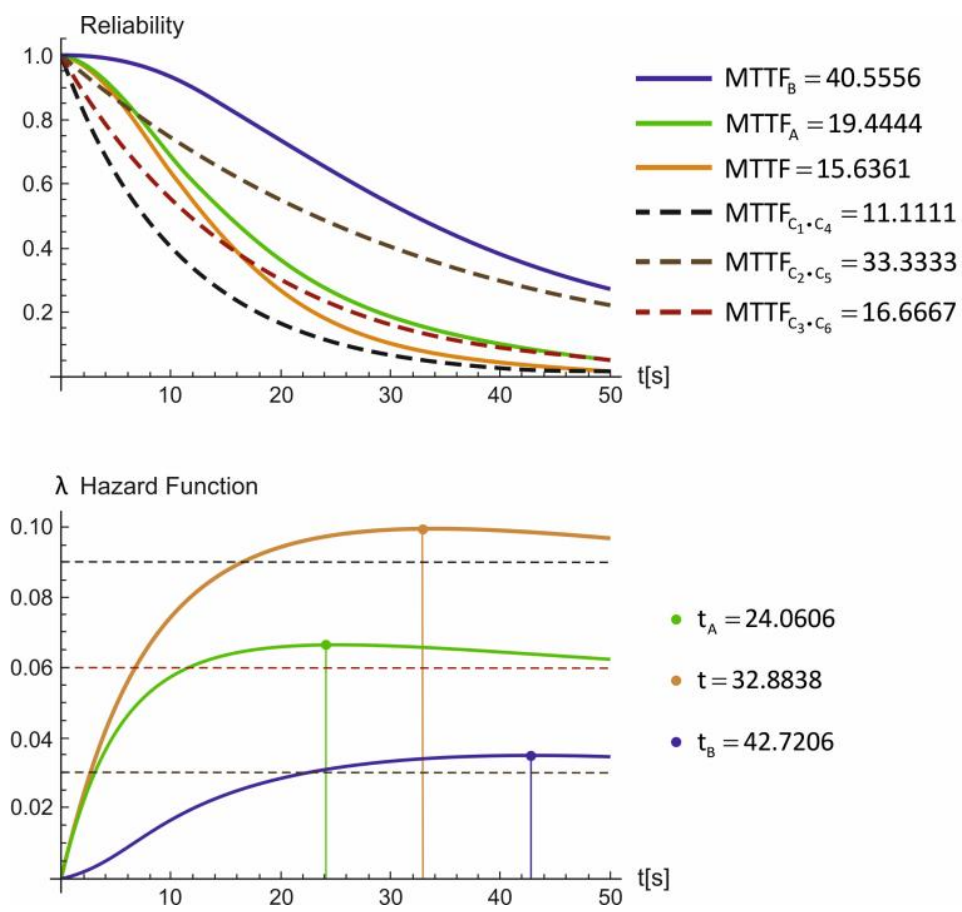

Fig. 3. Reliability and Hazard function for the analyzed system for $\mathbf{1 0 0 0}$ journeys 
Reliability model of the RTC System with trackside equipment equipped with a Peltier cell
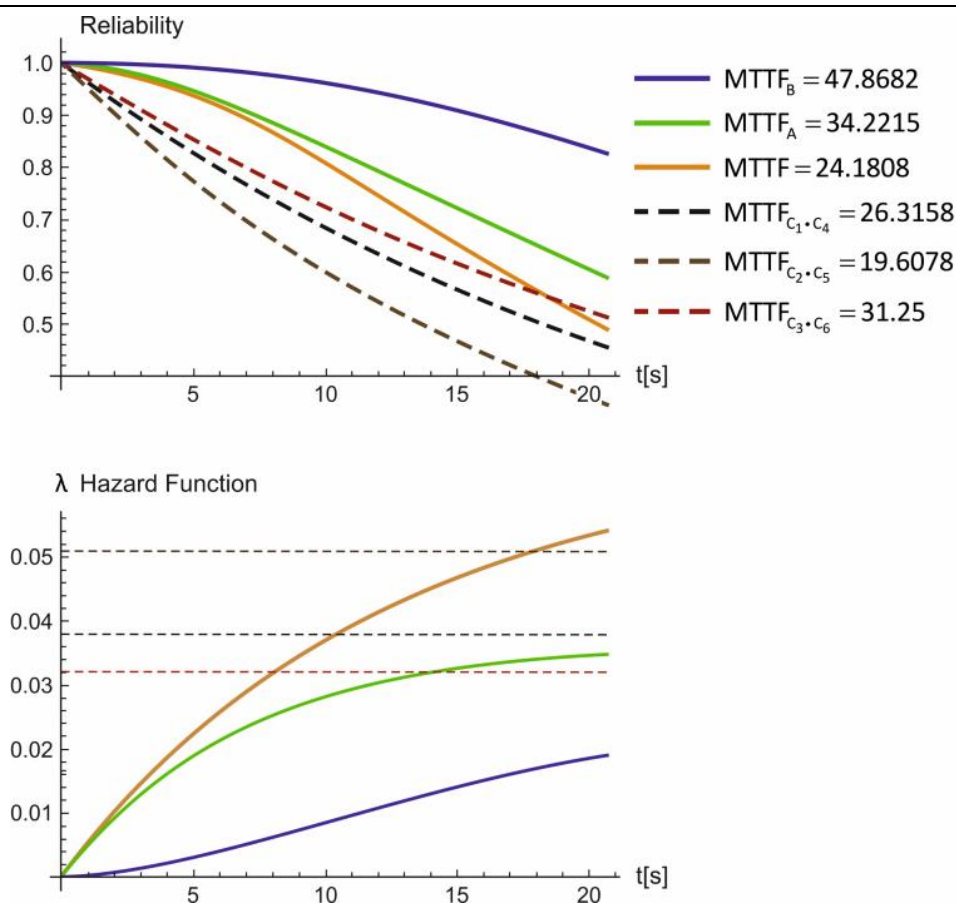

Fig. 4. Reliability and Hazard function for the analyzed system for $\mathbf{2 0 0 0}$ journeys
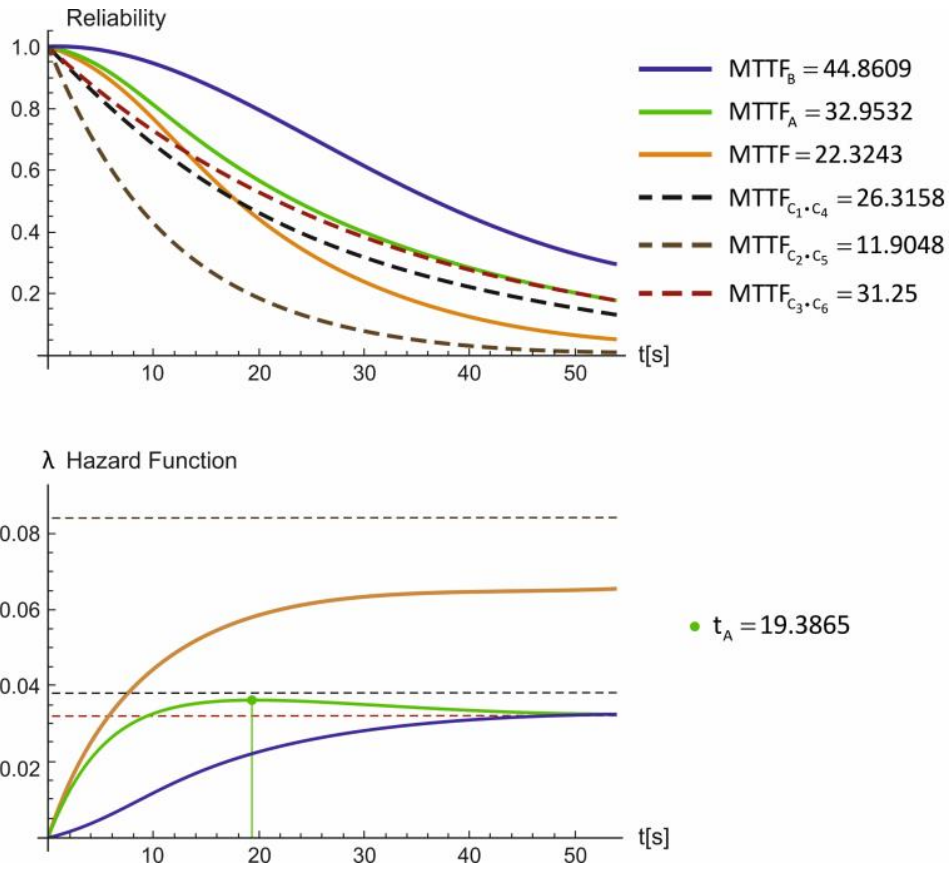

Fig. 5. Reliability and Hazard function for the analyzed system for $\mathbf{3 0 0 0}$ journeys 
However, the reliability of the railway contro center for the signaling system is not calculated, but management and maintenance in accordance with the principle of reliability and then reliability can be obtained through a statistical result of the time after the operation of the RTC System. The results of simulation tests showed that the developed simulation model of the RTC System with a Peltier cell corresponds to the actual operating conditions, while its refinement leads to increasingly precise forecasts of the system's operation. The probability of failure can be estimated using simulation algorithms generating Markov's chains. For this purpose it is necessary to use methods to determine the normalization constants. The examples presented have shown that using this approach requires a large number of simulations. However, the method discussed in the paper has been successfully used to solve a task in which the failure area is symmetrical in relation to the failure rate of various elements of the RTC enclosure. Moreover, test examples have shown that in case of low failure rates the effectiveness of these algorithms is significantly higher than in the traditional Monte Carlo method. The use of the Hazard function seems to be worth considering in the case of complex failure areas with multiple design points of the motion control systems. The achievement of the work is the development of a method for defining the survival function, which takes into account the "life" of all elements in the RTC cabinet with a Peltier cell.

In this work an attempt was made to indicate the probability of failure of technical system elements using a mathematical model (semibrand). The application of the semi-brand process theory to describe the reliability of complex technical systems in traffic control allows to distinguish the basic elements of the system which undergo the most frequent failure.

\section{MODEL NIEZAWODNOŚCI SYSTEMU SRK Z OSPRZĘTEM PRZYTOROWYM WYPOSAŻONYM W OGNIWO PELTIERA}

W artykule przedstawiono model matematyczny oceniający niezawodność systemów sterowania ruchem kolejowym z zamontowanym ogniwem Peltiera. Element półprzewodnikowy zostanie wykorzystany do obsługi elementów elektronicznych znajdujących się w urządzeniach torowych. W przygotowanym modelu wykorzystano procesy Markowa do opisu stanów występujących pomiędzy poszczególnymi elementami systemu SRK. Testy symulacyjne polegały głównie na określeniu średniego czasu uszkodzenia elementu. Przedstawione wyniki przeprowadzono dla 1000, 2000 i 3000 przejazdów pojazdów szynowych nad torami kolejowymi wyposażonymi w systemy SRK. Na samym końcu artykułu przedstawiono wnioski wynikające z symulacji komputerowych.

Słowa kluczowe: systemy sterowania ruchem SRK, MTTF, niezawodność, ogniwo Peltiera

\section{REFERENCES}

[1] Bobrowski D. (1985) Mathematical models and methods of reliability theory. WNT, Warsaw

[2] Digital Exchange Design Objectives - General (March 1994). ITU-T Recommendation. Q.541

[3] Kopociński B. (1973) An outline of the theory of renewal and reliability. PWN, Warsaw

[4] Migdalski J. (1982) Reliability Guide. Mathematical basics. WEMA Machine Industry Publishing House. Warsaw

[5] Oprzędkiewicz J., Młynarski S. (2000) "Problems of prediction of quality and reliability of motor vehicles. In Construction testing operation, technology of motor vehicles and internal combustion engines". Teka of the Scientific and Problem combustion engines". Teka of the Scientific and

[6] Oprzędkiewicz J. (1993) CAD CAM Computer support in machine reliability. WNT, Warsaw

[7] PN-77/N-04005 Reliability in technology. Indicators of reliability. Names of terms and symbols

[8] PN-93/N-50191 Electrical terminology dictionary. Reliability; quality of service

[9] Collective work edited by M. Prażewska: (1987) Reliability of electronic devices. WKŁ. Warsaw

[10] Prażewska M. (1987) Editor: Reliability of electronic devices. WKŁ Warsaw. Reviewer: prof. dr hab. Eng. Stanisław Cierpisz

[11] Rej A., Skoropacki W. Wojtas P. (2000) Report from the Research Project 9T12A 03116 Investigation of structural reliability of the mine telecommunications network. EMAG Center. Katowice

[12] Rej A., Skoropacki W., Wojtas P. Substantive report on the implementation of the Research Project 9T12A 03116 Investigation of structural reliability of the mine telecommunications network. Scientific and research work of the EMAG Center. Katowice

[13] ReliaSoft Corporation. Life Data Analysis Reference. Weibull ++ Reliasoft Publishing. Tucson AZ USA 2008

[14] Sergiejczyk M. (2008) Availability of the Motorway Emergency Communication. Journal of KONBiN 2(5)2008. ISSN 1895-8281. https://doi.org/10.2478/v10040-008-0053-3

[15] Sharma A. (2008) Performance Comparision of two Dynamic Shared-Path Protection Algorithms for WDM Optical Mesh Networks. University of Pretoria

[16] Szkoda M. (2014) Assessment of Reliability, Availability and Maintain-ability of Rail Gauge Change Systems. Operation and Reliability - Maintenance and Reliability, No. 6(3)

[17] Szopa T. (2009) Reliability and security. Warsaw University of Technology Publishing House. Warsaw

[18] Wojtas P. (2010) Impact of integration of dispatch systems and telecommunication network configuration on their reliability and functionality. Dissertation. The Silesian Technical University. Gliwice

[19] Żółtowski B., Cempel C. (ed.) (2005) Machine diagnostics engineering. ITeE, Radom

[20] Żółtowski B. (2012) Improving machine operation systems. Operation Problems

[21] Fei Yan, Tao Tang, (2005) "Research and Development of Safety Technology in Signaling System of Rail Transit", China Safety Science Journal (in Chinese), pp 23-26 


\section{Reliability model of the RTC System with trackside equipment equipped with a Peltier cell}

[22] Guo H. T. Yang X.H, (2008) "Automatic creation of Markov models for reliability assessment of safety instrumented systems", Reliability Engineering \& System Safety, Vol. 93, Issue 6, pp 829-837.

https://doi.org/10.1016/j.ress.2007.03.029

[23] Smith R.M. (1987) "Markov reward models: application domains and solution methods", Ph D thesis, Compute Science Dept., Duke University, Durham, NC, pp 15-18

[24] Ereau J.F., Saleman M., Valette R., et al. (1997) “Petri nets for the evaluation of redundant systems", Reliability Engineering \& System Safety, pp 95-104

[25] Manish M., Trivedi K.S. (1995) "Dependability Modeling Using Petri- Nets", IEEE Transactions on Reliability, pp 428-440. DOI: $10.1109 / 24.406578$
[26] Tomek L., Trivedi K.S. (1995) "Analyses using stochastic reward nets", Software Fault Tolerance, New York: John Wiley \& Sons, pp 139-166

[27] Liu S. X., Xu Z. C., Chen G. L., et al. (2009) "Dependability Research of Standby System Based on Stochastic Petri Net", Proceedings of the International Conference on Networks Security, Wireless Communications and Trusted Computing, pp 179-183.

DOI: 10.1109/NSWCTC 2009.373

[28] Nabil S., Hamid D. (2009) "Reliability analysis of discrete event dynamic systems with Petri nets", Reliability Engineering and System Safety, Vol. 94, Issue 11, pp 1848-1861. https://doi.org/10.1016/j.ress.2009.06.006 